\title{
DISEKSI ARTERI KAROTIS INTERNAL POSTPARTUM
}

\author{
POSTPARTUM INTERNAL CAROTID ARTERY DISSECTION \\ Jimmy, * Ashari Bahar, * Andi Kurnia Bintang, * Muhammad Iqbal Basri*
}

\section{ABSTRACT}

Internal carotid artery dissection is the most common cervicocephalic artery dissection. Postpartum cervicocephalic artery dissection is a rare cause of stroke in young adults. We report the case of a 27-year-old female presented to the emergency department with left hemiplegia occurred suddenly 4 days prior to admission when she was breastfeeding her 5-month-old baby in the afternoon, preceded by a right headache. She has a history of migraine and experienced repeated headaches with increased pain intensity after vaginal delivery to this baby. An early brain CT scan disclosed the presence of subacute massive cerebral infarction in the distribution of proximal right middle cerebral artery territory. A carotid doppler showed absence of flow velocity and tapering luminal narrowing in the right internal carotid artery. The diagnosis was confirmed using standard digital subtraction angiography (DSA) which showed a "flame sign" of the proximal right internal carotid artery with collateral circulation from anterior communicating artery and right posterior cerebral artery to right middle cerebral artery vascularization. She was treated with the combination of acetylsalicylic acid-clopidogrel and simvastatin. A repeated brain CT scan showed improvement compared to the early brain CT scan. She showed improvement of headache and motor function.

Keywords: Cervicocephalic artery dissection, DSA, migraine, postpartum, stroke in young adults

\section{ABSTRAK}

Diseksi arteri karotis internal merupakan kejadian tersering dari diseksi arteri servikosefalik. Diseksi arteri servikosefalik postpartum merupakan suatu penyebab stroke yang jarang pada usia muda. Dilaporkan kasus seorang perempuan 27 tahun dibawa ke unit gawat darurat dengan kelemahan tubuh sisi kiri secara tiba-tiba 4 hari sebelum masuk RS. Saat itu pasien sedang menyusui bayinya, didahului nyeri kepala sisi kanan. Pasien memiliki riwayat migren dan merasakan nyeri kepala berulang yang bertambah berat setelah melahirkan bayinya tersebut. CT scan kepala awal memperlihatkan adanya infark serebral masif subakut sesuai distribusi daerah proksimal arteri serebral media. Doppler karotis menunjukkan hilangnya kecepatan aliran dan penyempitan lumen bertahap di arteri karotis internal kanan. Diagnosis dikonfirmasi dari gambaran digital subtraction angiography (DSA) berupa flame sign di arteri karotis internal kanan bagian proksimal dengan sirkulasi kolateral dari arteri komunikans anterior dan arteri serebral posterior kanan ke vaskularisasi arteri serebral media kanan. Pasien diterapi dengan kombinasi asam asetilsalisilat-klopidogrel dan simvastatin. CT scan kepala kontrol memperlihatkan perbaikan dibandingkan dengan CT scan kepala awal. Pasien menunjukkan perbaikan nyeri kepala dan kekuatan motorik.

Kata kunci: Diseksi arteri servikosefalik, DSA, migren, postpartum, stroke usia muda

*Departemen Neurologi FK Universitas Hasanuddin/RSUP Dr. Wahidin Sudirohusodo, Makassar. Korespondensi: jimmy.jitacitto@ gmail.com.

Laporan kasus ini pernah dipresentasikan dalam bentuk e-Poster di acara Pertemuan Ilmiah Nasional Perdossi 26-29 April 2018, Bogor.

\section{PENDAHULUAN}

Diseksi arteri servikosefalik dijumpai sebanyak $2 \%$ dari kejadian stroke iskemik dan merupakan penyebab tersering stroke pada usia muda dan pertengahan. Kebanyakan pasien berusia 30-50 tahun dengan rerata sekitar 40 tahun. Pada pasien yang berusia kurang dari 45 tahun, diseksi arteri adalah penyebab stroke tersering kedua dengan $10-25 \%$ dari stroke iskemik. Diseksi arteri karotis internal merupakan kejadian tersering dari diseksi arteri servikosefalik, ${ }^{1}$ yang lebih jarang lagi pada keadaan postpartum, hanya sekitar $6 \%$ dari diseksi spontan pada perempuan di bawah usia 50 tahun. $^{2}$
Risiko relatif stroke iskemik selama kehamilan adalah 0,7 tetapi meningkat menjadi 8,7 selama periode postpartum. ${ }^{3}$ Hal ini diumungkinkan akibat perubahan pada volume intravaskular, efek perubahan hormonal selama kehamilan pada arteri-arteri serebral, lesi akut pembuluh darah serebral selama kelahiran, dan kelainan koagulasi darah yang meningkatkan risiko trombosis arterial. ${ }^{3}$

Diseksi arteri karotis internal dapat menyebabkan gejala-gejala iskemik yang oleh gangguan hemodinamik akibat penyempitan/oklusi lumen, tromboemboli, atau keduanya. Gambaran klinis utama diseksi karotis internal adalah nyeri kepala 
ipsilateral, wajah, atau leher yang bersamaan dengan gejala-gejala iskemik fokal (serebral atau retinal). ${ }^{1}$ Perlu diperhatikan bahwa nyeri kepala postpartum juga dapat disebabkan oleh muscle strain, dehidrasi, trombosis vena serebral, stroke hemoragik, dan lainlain, mengingat diseksi arteri karotis internal termasuk kasus yang jarang. ${ }^{2,4}$ Oleh karena itu, klinisi yang menangani pasien postpartum harus membiasakan diri dengan gambaran klinis dan strategi terapi untuk pasien dengan diagnosis yang tidak biasa ini. ${ }^{2}$

\section{KASUS}

Seorang perempuan 27 tahun dibawa ke unit gawat darurat RSUP Dr. Wahidin Sudirohusodo, Makassar dengan keluhan utama kelemahan tubuh sisi kiri secara tiba-tiba 4 hari lalu sebelum masuk RS. Saat itu pasien sedang menyusui bayinya di sore hari, disertai mulut mencong ke kanan, bicara pelo, dan rasa kram pada sisi tubuh kiri. Pasien juga mengeluh nyeri kepala kanan hebat secara terus menerus, terasa berdenyut di dahi, pelipis, puncak kepala, dan kadang-kadang di leher yang disertai mual sehingga mengganggu aktivitasnya.

Pasien memiliki riwayat migren sejak 1 tahun lalu. Namun nyeri kepala berulang dan bertambah berat setelah melahirkan 5 bulan lalu yang kadang membaik dengan obat nyeri. Riwayat melahirkan normal sebelumnya sebanyak 3 kali (termasuk saat ini). Tidak ada riwayat penyakit lain sebelumnya.

Pada pemeriksan umum, tanda-tanda vital normal dan skala nyeri (Numeric Rating Scale/NRS) 9. Pemeriksaan neurologis didapatkan paresis N. VII dan N. XII kiri tipe sentral, hemiplegia kiri, tonus dan refleks fisiologis menurun di sisi tubuh kiri, serta hemihipestesia kiri. Nilai National Institutes of Health Stroke Scale (NIHSS) adalah 12 dan modified Rankin Scale (mRS) adalah 5.

Pemeriksaan elektrokardiografi (EKG), ekokardiogram, foto toraks, darah rutin dan paramater biokimia dalam batas normal. CT scan kepala tanpa kontras awal memperlihatkan adanya infark serebral masif subakut sesuai distribusi daerah proksimal arteri serebral media dengan penyempitan ventrikel lateral kanan (Gambar 1A). Doppler karotis menunjukkan hilangnya kecepatan aliran dan penyempitan lumen bertahap di arteri karotis internal kanan (Gambar 2).

Diagnosis dikonfirmasi dengan digital subtraction angiography (DSA) standar yang menunjukkan gambaran oklusi bertahap seperti gambaran lilin berpijar/flame sign di arteri karotis internal kanan bagian proksimal dengan sirkulasi kolateral dari arteri komunikans anterior dan arteri serebral posterior kanan ke vaskularisasi arteri serebri media kanan (Gambar 3).

Pasien diterapi konservatif dengan kombinasi dua antiplatelet (asam asetilsalisilat 80mg per hari dan klopidogrel $75 \mathrm{mg}$ per hari), statin (simvastatin $20 \mathrm{mg}$ per hari), dan terapi suportif lainnya. CT scan kepala tanpa kontras kontrol dilakukan setelah pemberian terapi dan menunjukkan perbaikan dibandingkan dengan CT scan kepala yang pertama (Gambar 1B). Setelah 21 hari pengobatan, pasien diizinkan pulang dengan nyeri kepala ringan (NRS 1), NIHSS 9, dan mRS 4.

\section{PEMBAHASAN}

Diseksi arteri servikosefalik postpartum adalah kasus yang jarang dan hanya dijumpai sekitar $6 \%$ dari diseksi spontan pada perempuan berusia $<50$ tahun. ${ }^{3}$ Sejak tahun 1985 baru ada 27 kasus yang pernah dilaporkan. ${ }^{2}$

Diseksi lebih sering melibatkan segmen ekstrakranial karotis dibanding arteri vertebralis. ${ }^{3}$ Diseksi arterial biasanya diawali oleh robekan pada bagian intima yang memungkinkan terbentuknya suatu hematoma intramural (lumen palsu). Pada beberapa pasien, tidak dijumpai adanya hubungan antara lumen asli dan palsu yang menunjukkan bahwa beberapa kejadian diseksi merupakan hasil dari suatu hematoma intramedial primer. Lebih jauh lagi, disrupsi intima dapat terjadi sebagai hasil dari robeknya hematoma intramural primer ke bagian intima. Kedua mekanisme di atas dapat terjadi secara bersamaan, walaupun paling sering adalah terbentuknya hematoma intramural. ${ }^{1,5}$

Patogenesis dari kebanyakan diseksi arteri spontan tidak diketahui, dapat terjadi secara iatrogenik atau berhubungan dengan trauma berat. Beberapa kasus menunjukkan penyebab yang jelas dan spontan yang berhubungan dengan trauma sepele sebelumnya 


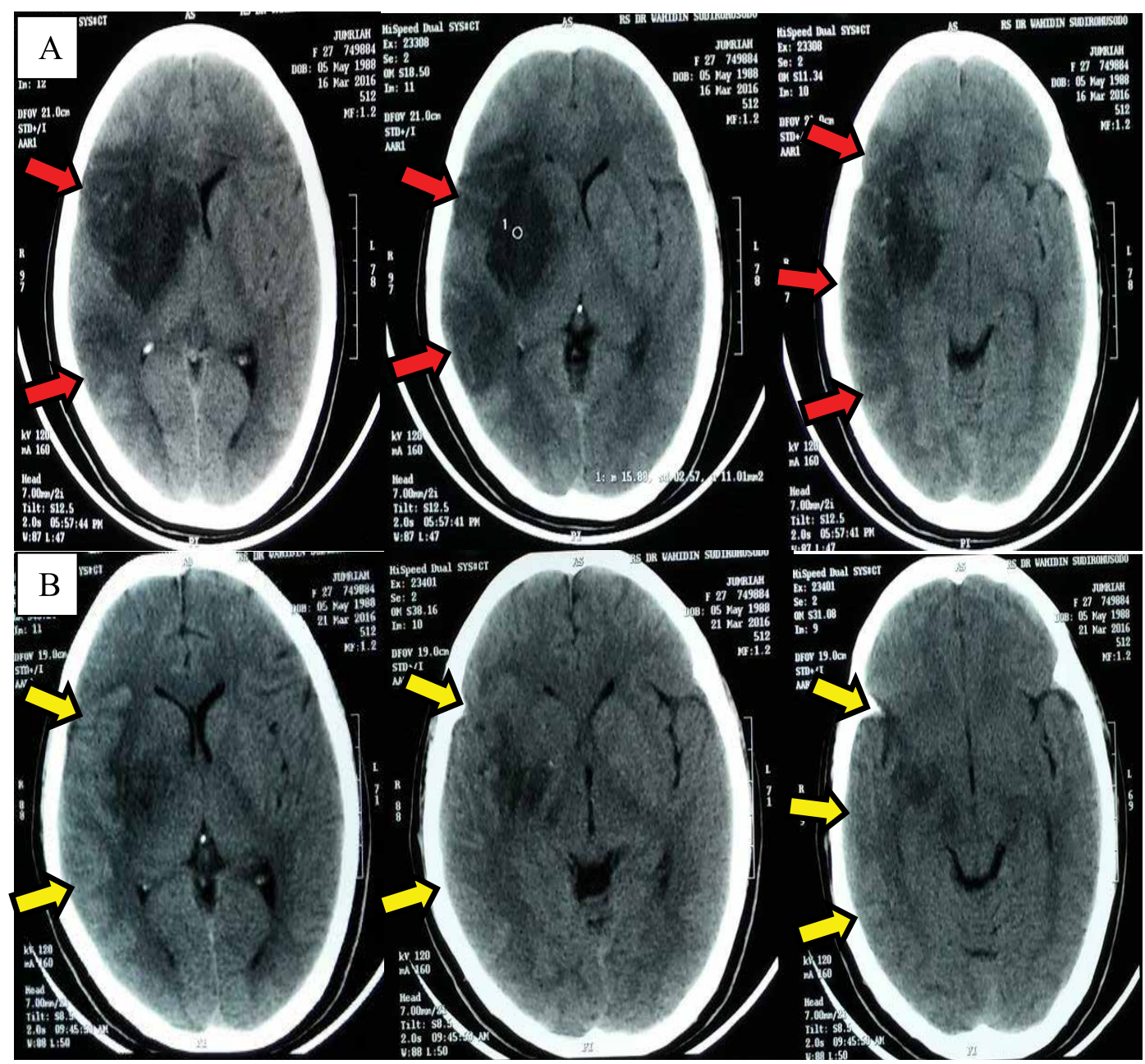

Gambar 1. CT Scan Kepala

A. Awal memperlihatkan infark serebral masif subakut sesuai distribusi daerah proksimal arteri serebral media kanan. B. Kontrol menunjukkan perbaikan.

yang menyebabkan cedera arteri akibat mekanisme peregangan, seperti pergerakan kepala yang tiba-tiba, batuk, muntah, bersin, manipulasi kiropratrik, yoga, mengecat langit-langit, menghembuskan hidung dengan kuat, aktivitas seksual, pemberian anestesi, resusitasi, ketegangan otot, dan aktivitas olahraga lainnya.

Sebanyak $5 \%$ pasien dengan diseksi servikosefalik spontan mempunyai riwayat satu anggota keluarga dengan diseksi spontan dari aorta atau cabang-cabangnya seperti arteri karotis dan vertebralis. Aterosklerosis bukanlah suatu faktor risiko. Faktor-faktor yang cenderung menyebabkan suatu diseksi adalah trauma, arteriopati, riwayat keluarga, migren, infeksi yang baru terjadi, hiperhomosisteinemia, dan yang jarang seperti kehamilan, postpartum, merokok, hipertensi, serta pengunaan kontrasepsi oral. ${ }^{1,5}$
Mekanisme terjadinya diseksi arteri karotis internal peripartum atau postpartum masih belum jelas. Walaupun dikaitkan dengan penyakit jaringan ikat, namun kebanyakan laporan diseksi postpartum terjadi pada perempuan muda yang sehat. ${ }^{2}$ Perubahan hormonal selama kehamilan dapat menimbulkan peningkatan volume intravaskular dan curah jantung, bahan-bahan vasoaktif serta degradasi kolagen yang mengakibatkan gangguan kualitas arteri dan pemenuhan arteri besar. ${ }^{2}$ Karkkainen dkk menunjukkan penurunan elastisitas arteri karotis pada akhir kehamilan dan tidak berhubungan dengan hiperlipidemia maupun diameter pembuluh darah. ${ }^{3,6}$

Estrogen memiliki efek proteksi vaskular karena memainkan peranan penting dalam homeostasis endotel dengan vasodilatasi endotel, mengurangi stres oksidatif, peningkatan produksi 


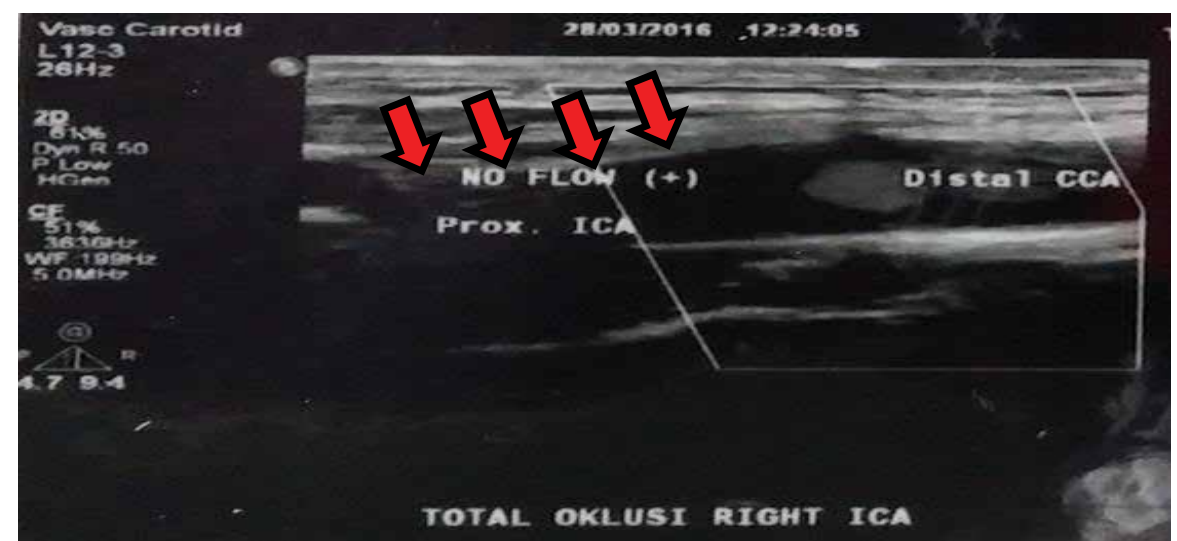

Gambar 2. Doppler karotis Menunjukkan Hilangnya Kecepatan Aliran dan Penyempitan Lumen Bertahap di Arteri Karotis Internal Kanan

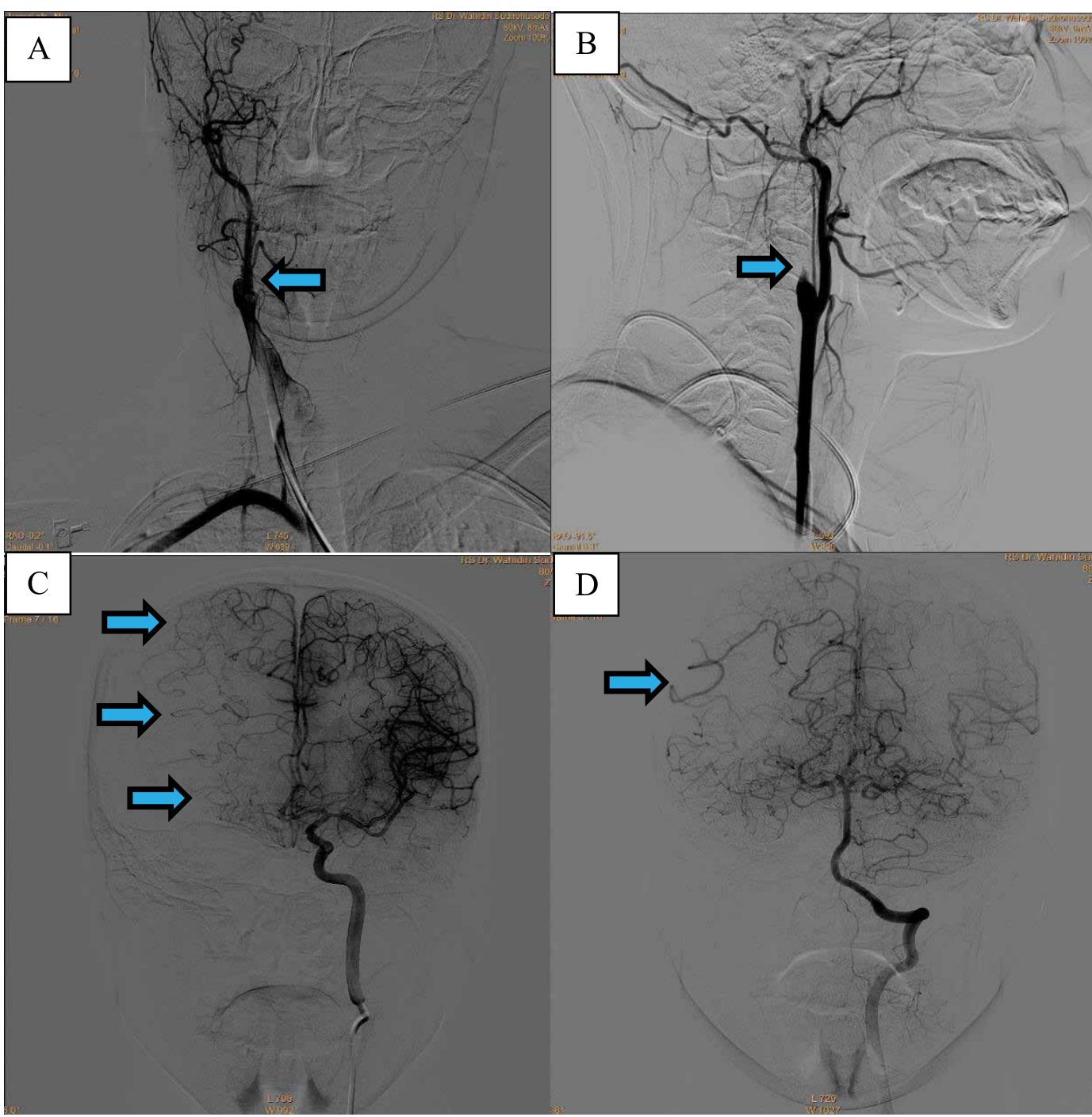

Gambar 3. Digital Subtraction Angiography Menunjukkan Gambaran Oklusi Total

(A) dan oklusi bertahap seperti gambaran lilin berpijar/flame sign; (B) di arteri karotis internal kanan bagian proksimal, sirkulasi kolateral dari arteri komunikans anterior; (C) dan arteri serebral posterior kanan; (D) ke vaskularisasi arteri serebri media kanan. 
antioksidan, dan mengurangi proses inflamasi. Namun kadar estrogen menurun pada periode postpartum..$^{7-8}$ Tunika media arteri karotis komunis lebih tipis dibanding dengan lapisan intima dan mempunyai rasio intima/media yang tinggi selama kehamilan. Rasio ini tergantung pada usia, tingkat estradiol, tekanan darah, dan indeks massa tubuh dari seorang ibu. ${ }^{9}$

Tunika media yang lebih tipis dapat menjadi lesi traumatik, kecuali arteri intrakranial dengan tunika adventisia yang sangat tipis dan tidak dijumpai lamina elastik eksternal. Pada pasien dengan diseksi arteri karotis internal postpartum, proses melahirkan lebih banyak melalui cara normal. Hanya pada dua kasus yang merupakan efek tekanan intratorakal positif (manuver Valsava) selama melahirkan ditiadakan karena proses kelahiran dilakukan dengan operasi caesar. Pada dua kasus lainnya, proses melahirkan dilakukan dengan operasi caesar setelah cara melahirkan normal tidak berhasil. Selama manuver Valsava, kecepatan aliran darah serebral dapat meningkat sampai $50 \%$ dan hal ini dapat berefek pada lapisan intima arteri. ${ }^{2-3}$

Hubungan antara migren dan diseksi arteri karotis internal masih belum jelas. Penelitian metaanalisis terbaru melaporkan bahwa migren dapat mengakibatkan kejadian diseksi arteri karotis internal sebanyak dua kali lipat. Hal ini dikaitkan bahwa pada pasien migren terdapat peningkatan aktivitas serum elastase yang terlibat dalam degradasi matriks. ${ }^{10}$

Pada pasien ini, gejala migren yang semakin memberat diduga merupakan gejala awal terjadinya diseksi arteri karotis internal setelah melahirkan, karena gejala yang paling jelas terlihat pada awalnya adalah nyeri kepala ipsilateral. ${ }^{1}$ Migren sendiri dapat meningkatkan risiko kejadian diseksi arteri karotis internal, ${ }^{10}$ ditambah pasien ini memiliki risiko lain, yaitu postpartum. ${ }^{1}$ Hal ini semakin dibuktikan dengan keluhan migren yang semakin berkurang pascapengobatan kombinasi antiplatelet sebagai pencegahan stroke rekuren dan analgetik nonspesifik.

Diseksi arteri karotis internal dapat menyebabkan gejala-gejala iskemik karena gangguan hemodinamik yang disebabkan oleh penyempitan atau oklusi lumen, tromboembolisme, atau keduanya. Gambaran klinis utama yang jelas terlihat pada diseksi karotis ekstrakranial adalah nyeri pada kepala, wajah, atau leher ipsilateral yang bersamaan dengan gejala-gejala iskemik fokal (serebral atau retinal). Pada sepertiga kasus dapat dijumpai sindrom Horner parsial, sedangkan kelumpuhan saraf kranial sebanyak $12 \%{ }^{1}$

Ketika dicurigai adanya gambaran klinis terkait dengan diseksi arteri serebrovaskular baik spontan atau traumatik, harus segera dilakukan pendekatan diagnostik yang agresif. Pemeriksaan carotid doppler ultrasound menunjukkan penurunan maupun hilangnya kecepatan aliran dan penyempitan lumen bertahap pada arteri yang terkena (Gambar 2).

Angiografi konvensional merupakan tes definitif yang akurat menunjukkan tingkat yang pasti dan daerah arteri yang mengalami diseksi, serta gambaran komplikasi terkait diseksi. Pemeriksaan ini walaupun bersifat invasif, namun dapat menunjukkan kelainan yang berhubungan dengan diseksi, termasuk gambaran sirip intima, bekuan intraluminal, oklusi bertahap seperti gambaran lilin berpijar/flame sign (Gambar 3B), lumen ganda, stenosis pembuluh darah dengan string sign dan formasi diseksi aneurisma. ${ }^{1}$

Pada pasien ini didapatkan nyeri kepala kanan yang bertambah berat setelah melahirkan yang sering dijumpai sebagai gejala awal diseksi arteri karotis internal, diikuti stroke 5 bulan kemudian tanpa faktor risiko stroke lainnya. Pada pemeriksaan Doppler karotis menunjukkan penyempitan lumen arteri karotis internal bertahap dan DSA menunjukkan gambaran flame sign yang sesuai untuk suatu diseksi arteri karotis internal.

Strategi optimal untuk pencegahan stroke pada pasien dengan diseksi arteri masih kontroversi. Beberapa pilihan adalah terapi antikoagulan, antiplatelet, angioplasi dengan atau tanpa stenting, atau observasi konservatif tanpa terapi medis spesifik. ${ }^{11}$ Meskipun pemberian terapi antitrombotik pada diseksi serebrovaskular ekstrakranial masih kontroversi dan kurangnya penelitian skala besar, pengobatan didasari oleh terapi empiris dan observasi klinis bahwa kebanyakan cedera arteri serebral pada 
kasus akut merupakan hasil dari kejadian trombotik terutama emboli arteri ke arteri. ${ }^{1}$

Pengobatan antitrombotik, baik dengan antikoagulan (heparin, low-molecular-weight heparin, atau warfarin) atau antiplatelet (aspirin, klopidogrel, kombinasi aspirin, dan dipiridamol lepas lambat) minimal 3-6 bulan dapat diberikan pada pasien-pasien dengan diseksi arteri karotis atau vertebralis ekstrakranial yang berhubungan dengan stroke iskemik atau transient ischemic attack (Class IIa; Level of Evidence: B). ${ }^{11}$ Pasien ini mendapatkan kombinasi aspirin dan klopidogrel, pasien menunjukkan perbaikan klinis. Antikoagulan tidak diberikan karena risiko terjadinya transformasi hemoragik berdasarkan gambaran CT scan kepala, adanya infark serebral luas disertai penyempitan ventrikel.

Keluaran klinis pada diseksi arteri bukan hanya tergantung pada derajat rekanalisasi akan tetapi juga kemampuan untuk menyuplai aliran kolateral melalui sirkulus Willis. Aktivasi dari dua atau lebih aliran kolateral menunjukkan perbaikan defisit neurologis setelah stroke yang disebabkan oleh diseksi arteri servikosefalik dan merupakan tanda penting untuk keluaran yang baik pada pasien. ${ }^{3}$ Pasien ini mendapatkan aliran kolateral terutama dari arteri komunikans anterior dan arteri serebral posterior kanan berdasarkan gambaran DSA.

\section{KESIMPULAN}

Diseksi arteri karotis internal merupakan suatu kondisi yang tidak boleh diabaikan dalam hal diagnosis banding kasus nyeri kepala postpartum dengan atau tanpa riwayat migren, konsekuensi dari terlambatnya diagnosis dan pengobatan yang tidak tepat dapat mengakibatkan defisit neurologis yang berat dan permanen.

\section{DAFTAR PUSTAKA}

1. Grotta JC, Albers GW, Broderick JP, Kasner SE, Lo EH, Mendelow AD, dkk. Stroke: pathophysiology, diagnosis, and management. Neurology. 2015;35:599608.

2. Kelly JC, Safain MG, Roguski M, Edlow AG, Malek AM. Postpartum internal carotid and vertebral arterial dissections. Obstet Gynecol. 2014;123(4):848-56.

3. Vukicevic M, Brkic BG, Ducic TJ, Bezmarevic ST, Culafic S. Dynamic nature of postpartal carotid artery dissection. Serbian J Exp Clin Res. 2016;17(2):167-74.

4. Lim SY, Evangelou N, Jurgens S. Postpartum considerations. Pract Neurol. 2014;14:92-9.

5. Blum CA, Yaghi S. Cervical artery dissection: a review of the epidemiology, pathophysiology, treatment, and outcome. Arch Neurosci. 2015;2(4):e26670.

6. Karkkainen H, Saarelainen H, Valtonen P, Laitinen T, Raitakari OT, Juonala M, dkk. Carotid artery elasticity decreases during pregnancy-the cardiovascular risk in Young Finns study. BMC Pregnancy Childbirth. 2014;14(1):98.

7. Iorga A, Cunningham CM, Moazeni S, Ruffenach G, Umar S, Eghbali M. The protective role of estrogen and estrogen receptors in cardiovascular disease and the controversial use of estrogen therapy. Biol Sex Differ. 2017;8(1):33.

8. Bermudez CM. Update on the neurobiological aspects of postpartum depression. EC Neurology. 2017;6:31-8.

9. Akhter T, Larsson A, Larsson M, Wikstrom AK, Naessen T. Artery wall layer dimensions during normal pregnancy: a longitudinal study using noninvasive high-frequency ultrasound. Am J Physiol Heart Circ Physiol. 2013;304(2):H229-34.

10. Spalice A, Del-Balzo F, Papetti L, Zicari AM, Properzi $\mathrm{E}$, Occasi F, dkk. Stroke and migraine is there a possible comorbidity? Ital J Pediatr. 2016;42(1):41.

11. Kernan WN, Ovbiagele B, Black HR, Bravata DM, Chimowitz MI, Ezekowitz MD, dkk. Guidelines for the prevention of stroke in patients with stroke and transient ischemic attack: a guideline for healthcare professionals from the American Heart Association/American Stroke Association. Stroke. 2014;45(7):2160-236. 